\title{
EVALUATION OF BIOCHAR AS PRIMING AGENT FOR FINGER
}

\section{MILLET (ELUSINECORACANA) SEED PRIMING}

\section{KIRUTHIGA ${ }^{1}$, G. SASTHRI ${ }^{1}$, P. SRIMATHI ${ }^{1}$ \& E. PARAMESWARI ${ }^{2}$}

${ }^{1}$ Department of Seed Science and Technology, Tamil Nadu Agricultural University, Coimbatore, Tamil Nadu, India

${ }^{2}$ Department of Environmental Science, Tamil Nadu Agricultural University, Coimbatore, Tamil Nadu, India

\begin{abstract}
A study was carried out to evaluate biochars viz., redgram, soapbush wattle (Acacia holosericiae) and water hyacinthas priming agent for finger millet seed priming. The experiment was conducted with biochar extracts made to different concentrations viz., 1,2,3,4 and 5 per cent solution. The performance of biochar extracts were evaluated in terms of physiological seed quality parameters like speed of emergence, germination, root length, shoot length, dry matter production and vigour index. The individual results revealed that priming of finger millet seed with redgrambiochar @ $4 \%$ solution secured the best results in all physiological parameters when compared to control. Similarly, seed primed with soap bush wattle and water hyacinth biochars also showed greater increase in all the physiological parameters at $1 \%$ and 4\% solution respectively compared to control. Among the biochars investigated, redgrambiochar primed seeds produced the vigorous seedlings followed by soapbush wattle. The biocharseed priming has a large scope in sustainable agriculture because of its significant improvement in physiological parameters for finger millet which is mostly cultivated as dryland crop.
\end{abstract}

KEYWORDS: Seed Priming, Biochars, Finger Millet, Improved Germination \& Vigour

Received: Mar 25, 2019; Accepted: Apr 15, 2019; Published: May 02, 2019; Paper Id.: IJASRJUN201917

\section{INTRODUCTION}

Seed quality is one of the prerequisite for improving the germination and yield of plants, which done through seed management techniques (Komala et al., 2011). Among the seed quality enhancement techniques, seed priming plays a major role in the recent years which means the controlled dehydration of seeds to a level that permit pregerminative metabolic activity to proceed but prevent actual emergence of radicle which increase the speed and uniformity in germination under the adverse condition of temperature. In recent days sustainable agriculture is getting increased through which we can supply the organic and nutrient rich products. In this line, biochara carbon rich material was used as priming material. Biochar is obtained by the pyrolysis process. In simpler terms, the biomass such as wood/manure /leaves is heated in no availability of air (Lehmann et al., 2009). It is hyroscopic in nature and reduces the leaching effect which increased the root dry weight Robertson et al., 2012. It also aided to control global warming owing to its potential for reducing the emission of greenhouse gases in contrast to open air burning and decay of organic matter. In addition, biochar helped the sustainable management of massive agricultural and industrial waste (Woolf et al., 2010).

Because of its hygroscopic nature, in most of the investigations the biochar was used as soil application which need high amount of biochar. But in the present study, the biochar was used for seed enhancement technique through seed priming which need only little amount of biochar. This study was initiated to investigate the priming 
effect of different biochars in finger millet seed. Finger millet is one of the nutricereals which is gaining more value as compared to other fine cereals like rice and wheat. It is cultivated for about 61.36 ha with the productivity of $1865 \mathrm{~kg} / \mathrm{ha}$ in Tamil Nadu (Indiastat, 2017). Finger millet has an interesting fact that it is certain crop for the uncertain condition because it is mainly cultivated in rain fed areas (Sakamma et al., 2017). It is considered as an important neutraceutical crop. Hence the priming treatment with different biochars were experimented in this crop seed to improve the germination and other physiological parameters which will be beneficial to the sustainable agriculture.

\section{MATERIALS AND METHODS}

The basic seed material of finger millet (Elusinecoracana) cv. CO 15 was collected from the Department of Millets, Tamil Nadu Agricultural University, Coimbatore. The biochar viz., redgram and soapbush wattle (Acacia holosericiae) derived from stalks were obtained from Dryland Agricultural Research Station, Chettinad and water hyacinth derived from whole plant obtained from Department of Environmental Sciences, Tamil Nadu Agricultural University, Coimbatore. Then these biochars were ground and sieved to get fine powder. The laboratory studies were carried out in the Department of Seed Science and Technology, Tamilnadu Agricultural University, Coimbatore.

\section{Preparation of Biochar Extract for Priming}

The biochar extracts were prepared by immersing the biochars for different durations viz.,6, 12 and 24 hours in water/ethanol based on the solubility of biochar. The redgram and water hyacinthbiochars are soluble in water and soapbush wattle is soluble in ethanol. That biochars are to be soaked for 24 hours to get maximum extraction of nutrients from the biochars and then concentration was made to different per cent solutions like 1,2,3,4 and 5\%. The solutions were obtained by filtering through whatman number filter paper inorder to get the clear solution. After obtaining the solution, the finger millet seed was primed by adopting the seed to solution ratio of 1:1 and soaking duration of 6 hours and then dried back to original moisture content.

\section{Speed of Germination}

For each treatment twenty five seeds of four replicates were sown in petriplate top of paper method as per ISTA, 2013[7]. The seeds which are exposing the plumule were counted daily from the date of sowing until the final count day. Based on the seeds germinated, the speed of emergence was calculated using the following formula and the result was expressed in whole number (Maguire, 1962)

Speed of germination $=\frac{X_{1}}{Y_{1}}+\frac{X_{2}-X_{1}}{Y_{2}}+\ldots \ldots \ldots . .+\frac{X_{n}-X_{n-1}}{Y_{n}}$

X1- Per cent seeds germinated at first count

X2- Per cent seeds germinated at second count

Xn- Per cent seeds germinated on nth day

Y1- Number of days from sowing to first count

Y2- Number of days from sowing to second count

Yn- Number of days from sowing to nth count 


\section{Germination Test}

The germination test was conducted in the roll towel method in which the germination paper was used as the media. For each treatment, four replicates of hundred seeds were sown for conducting the germination test and kept in the germination room which is maintained at a temperature of $25 \pm 2^{\circ} \mathrm{C}$ and $95 \pm 1 \% \mathrm{RH}$. Then the final count was taken on eighth day where the seedlings were evaluated as normal, abnormal, dead seeds as per ISTA, 2013. The germination per cent was calculated using the following formula by using normal seedlings and then expressed in percentage.

$$
\text { Germination }(\%)=\frac{\text { Number of normal seedlings }}{\text { Total number of seeds sown }} \times 100
$$

\section{Shoot Length $(\mathbf{C m})$}

Shoot length was taken from ten normal seedlings which was selected randomly from every replication and length was measured from the collar region to the tip of primary leaf (plumule) which was expressed in $\mathrm{cm}$.

\section{Root Length $(\mathbf{C m})$}

The same seedlings which was evaluated for shoot length was measured for the root length from collar region to tip of root (radicle) and expressed in $\mathrm{cm}$.

\section{Dry Matter Production (g/10 Seedlings)}

Ten normal seedlings were selected from each treatments and replications and shade dried for 24 hours and was kept in hot air oven at $85^{\circ} \mathrm{C}$ for about 48 hours. After drying period, the seedlings were cooled in closed desiccators over $\mathrm{CaCO} 3$ and were weighed in balance and the mean were expressed as dry matter production in gram per 10 seedlings.

\section{Vigour Index}

Based on the data obtained from germination per cent and seedling length, the vigour index values were computed using the following formula for each treatments and replications and the mean expressed in whole number (Abdul Baki and Anderson, 1973)

Vigour index $=$ Germination \% $\mathrm{x}$ Seedling length in $\mathrm{cm}($ Root length + Shoot length)

\section{Statistical Analysis}

Data obtained were analysed for F test of significance following the methods described by Panse and Sukhatme (1985). Wherever necessary the values in the percent data were transformed using arcsine transformation.

\section{RESULTS AND DISCUSSIONS}

Priming of seeds is nothing but the soaking of seeds in solution, but restricts radicle protrusion until the primed seed are sown for germination (Vaibhav et al., 2017). So far many investigators used variety of priming agent for seed priming. But none of them used biochar as seed priming agent for improving the germination and other quality parameters. We are the pioneer in this study and used extracts derived from three different biochars as priming agent. The biochars viz., redgram, soapbush wattle, water hyacinth were used in different concentrations to evaluate the effect of type of biochar and also the concentration of biochar for priming of finger millet seed. 
While evaluating the individual biochar, the biochar derived from redgram feedstock recorded significant differences for all the seed quality parameters studied. On comparison of different concentrations of biochar used, it was noted that $4 \%$ concentration was better than lower concentrations (1, 2 and 3\%). Eventhough beyond 4\%concentration, while the next level concentration of $5 \%$ was used, all the seed quality parameters were decreased but it was not less than control (Table 1). From this study, it was known that $4 \%$ redgram biochar could be used for priming of finger millet seed which improved the speed of germination, germination per cent, seedling length, dry matter production and the computed vigour index value to a tune of $27 \%, 21 \%, 20 \%, 23 \%, 47 \%$ and $48 \%$ respectively higher than control. Increased germination and seedling vigour through the biochar priming was due to presence of nutrients and nature of biochar that has been primed with seeds which was responsible for lesser inhibitory growth for seed germination. This was in line with Major (2009)in lettuce, radish and clover who used the biochar as soil amendment.

Biochar contains macro and micronutrients viz., N, P, K, Ca, Mg, $\mathrm{Cu}, \mathrm{Fe}, \mathrm{Mn}$ and $\mathrm{Zn}$. Among the nutrients of biochar, calcium acted as enzyme cofactor in the process of germination which leads to increase in protein synthesis as reported by Christansen and Foy, 1979. The variation in physiological parameters obtained at different concentration was due to biphasic nature of biochar i.e. at low concentration it promotes the plant growth and vice versa at higher concentration (Muhammad et al., 2018). Zakaria et al., 2011 had also proved that all the plant attributes were decreased at higher concentration of biochar application in subterranean clover. The growth parameters like root length and shoot length was increased in biochar primed seeds because of the fertilizing effect of biochar resulted in nutrient release from damaged or decayed tissue of storage organ by hydrolysis as reported in sorghum (Shehzad et al., 2012). The addition of biochar improved the shoot length of lettuce plant (Mendez et al., 2017). Root biomass was increased by $20 \%$ due to application of biochar in wheat as revealed by Gebremedhin et al., 2015. Whereas the root length was increased under drought condition to absorb water from deep soil (Nahar and Gretzmacher, 2011, Yousara et al., 2017) which was observed in soybean seedlings under drought stress. The increase in dry weight was due to early vigour and higher germination per cent because of which seedling reached the autotrophic stage in advance than in control (Srimathi et al., 2007) which produced relatively higher amount of dry matter as reported in greengram. Yue et al., 2017 observed that application of sludge derived biochar to the soil which significantly stimulated the growth and weight of turf grass by mineral nutrition enhancement in plant. In another study Khan et al., 2013 revealed that growth parameters of rice were increased due to application of nutrient rich sewage sludge biochar. The increase in vigour index was due to inducement of growth promoting substances and translocation of secondary metabolites to the seedling growth.

For evaluation of type of biochar, the biochar from another feed stock soap bush wattle at various concentrations were used as priming agent for finger millet seed. In contrast to redgram biochar, where $4 \%$ concentration was better than 1,2 and $3 \%$ concentration, maximum speed of germination (4.82), germination per cent (91\%), shoot length (4.2 cm), root length $(13.3 \mathrm{~cm})$, dry matter production $(0.028 \mathrm{~g} / 10$ seedling) and vigour index $(1591)$ were recorded in soap bush wattle biochar at the lowest concentration i. e. 1\% rather than other concentrations and control (Table 2). The use of soapbush wattle biochar after $1 \%$, gradually reduced the seed quality parameters due to the reason as dealt in redgram biochar. As that of redgram biochar, the biochar derived from water hyacinth revealed that $4 \%$ concentration was better than lower concentration of 1,2 and $3 \%$. Here also the higher concentration $5 \%$ reduced the physiological parameters studied (Table 3). The reason was already discussed in the redgram biochar chapter. 
Eventhough the individual biochars recorded higher values at different concentrations, all the biochars had significant effect in seed quality parameters. While comparing the three biochars, the redgram biochar out beated the other two biochars interms of vigour index. Regarding germination per cent, redgram biochar is on par with soapbush wattle biochar (Figure 1). The usage of a particular type of biochar is its intrinsic nutrient composition (rich or poor), which could produce varying results in the form of significant differences in plant growth (Deeniket al., 2016, Kim et al., 2013). This was in accordance with Gaskin et al. (2008), who reported that depending on the biomass type from which biochar is produced, biochar may contain traces to high concentrations of nutrients that could affect seed germination. Zakaria et al. (2011) also studied the influence of biochar type and rate on seed germination and seedling growth and reported the variation among the biochars. Root / shoot ratio decreased with higher rate of biochar application. Wheat seed germination was stimulated at 10t/ha soil application of biochar, but not for mung bean, inhibition of biochar occurred at the highest rate $100 \mathrm{t} /$ ha under the bioassay condition.

\section{CONCLUSIONS}

The finger millet seed priming with biochar as priming agent was influenced by type of biochar and concentration. All the biochars individually improved the seed quality parameters viz., speed of germination, germination per cent, root length, shoot length, dry matter production and vigour index at different concentrations. Among the three biochars investigated, redgrambiochar produced more vigorous seedlings than other two biochars viz., soapbush wattle and water hyacinth. From this study it is known that biochars have the great potentiality in seed enhancement treatment especially for sustainable agriculture.

\section{REFERENCES}

1. Abdul baki, A. A, \&Anderson, J. D. (1973). Vigour determination in soybean seeds by multiple criteria. Crop Science. 13,630-633.

2. Christansen, M. N, \&Foy, C. D. (1979). Fate and function of calcium in tissue. Communication in Soil Science and Plant Analysis. 10, 427-442.

3. Deenik, J. L, \& Cooney, M. J. (2016). The potential benefits and limitations of corn cob and sewage sludge biochars in an infertile oxisol. Sustainability. 8, 131.

4. Gaskin, J. W, Steiner, C, Harris, K, Das, K. C\& Bibens, B. (2008). Effect of low temperature pyrolysis conditions on biochar for agricultural use. T Asabe. 51, 2061-2069.

5. Gebremedhin, G. H, Berekethaileselassie, Daniel berhe \& Tesfaybelae. (2015). Effect of biochar on yield and yield components of wheat and post harvest soil properties in tigray, etiopia. Journal of agricultural science and food research. $6,158$.

6. https://www.indiastat.com.2017.

7. ISTA. International rules for seed testing. (2013). Seed Science Technology. Supplement Rules: 27-57.

8. Khan, S, Chao, C, Waqas, M, Arp H. P. H, \&Zhu, Y. G.(2013). Sewage sludge biochar influence upon rice (Oryzasativa L.) yield, metal bioaccumulation and greenhouse gas emissions from acidic paddy soil. Environmental Science and Technology. 47, 8624-32 
9. Kim, T. H, Kim, K. M, Manigbas, N. L, Yi, G. H \& Sohn, J. K. (2013). Identification of quantitative trait loci for resistance to white-backed planthopper (Sogatellafurcifera) in rice with Milyang 46 (Cheongcheongbyeo) background. Phillipine Journal of Crop Sciences. 38(2), 30-36.

10. Komala, N, Basavaarya, B. R, Sumalatha, G. M, Gurumurthy, $R$ \& Surendra P. (2018) seed quality enhancement techniques. Journal of pharmacognosy and phytochemistry.3124- 3128.

11. Lehmann, J. Bioenergy in the black. (2007). Frontiers in Ecology and the Environment.5,81-387

12. Maguire, J. D. Speed of germination - Aid in selection and evaluation of seedling emergence and vigour. (1962). Crop Science. 2, 176-177.

13. Vanitha, C., \& Kathiravan, M. Response of Blackgram (Vigna Mungo. L) to Seed Bio-Fortification and Foliar Nutrition Intervention in Relation to Seed Quality and Yield Potential.

14. Major, J, Rondon, M, Molina, D, Riha, S. J \& Lehmann, J. (2010). Maize yield and nutrition during 4 years after biochar application to a Colombian savannaoxisol. Plant and Soil. 333, 117.

15. Mendez, A, Cardenas-Aguiar, E, Paz-Ferreiro, J, Plaza, C\&Gasco, G. (2017). The effect of sewage sludge biochar on peatbased growing media. Biological Agriculture \& Horticulture. 33(1), 40-51.

16. Muhammad waqas, Raheemshahzad, Muhammad hamayun, Sajjadasaf, Abdul latif khan, Sang-mokang, Sopheapyun, Kyung min kim\&In- jung lee. (2018). Biochar amendment changes jasmonic acid level in two rice varieties and alters their resistance to herbivory. PLoS ONE. 13(1), 1-18

17. Nahar, $K \&$ \&retzmacher, R. Response of shoot and root development of seven tomato cultivars in hydrophonic system under water stress. (2011). American Journal of Plant Sciences. 4(2), 57-63.

18. Panse, V. G\& Sukhatme, P. V. (1985). Statistical methods for Agricultural workers. ICAR, Publication, New Delhi. $327-340$.

19. Robertson, J. S, Michael Rutherford, P, Lopez Gutierrez \& Massicotte, H. B. (2012). Biochar enhances seedling growth and alters root symbioses and properties of sub boreal forest soils. Canadian Journal of Soil Science. 92,329-340.

20. Shivakumar, K. V., Devendra, R., Muniswamappa, M. V., Halesh, G. K., \& Mahadevamurthy, M. (2014). Weed seed production potentials in Bidens pilosa L. in plantation crops in hill zone of Karnataka. International Journal of Research in Applied, Natural and Social Sciences (IJRANSS), 2, 11-18.

21. Sakamma, S, Umesh, K. B, Girish, M. R, Ravi, S. C, Sathishkumar \& Veerabhadrapanbellundagi. (2018). Finger millet (ElusinecoracanaL. Gaertn.) production system: status, potential, constraints and implication for improving small farmers welfare. Journal of agricultural scinces. 10,162-179

22. Shehzad, M., Ayub, A. M, Ahmad, U. H\& Yaseen, M. (2012). Influence of priming techniques on emergence and seedling growth of forage sorghum (Sorghum bicolor L.). Journal of Animal and Plant Sciences. 22(1), 154-158.

23. Srimathi, P, Kavitha, S \& Renugadevi, J. (2007). Influence of seed hardening and pelleting on seed yield and quality in greengram (Vignaradiata L.) cv. CO 6. Indian Journal of Agricultural Research. 41(2), 122-126.

24. Vaibhavpradhan, Prashantkumarrai, Bara, B. M \& Srivastav D. K. (2017). Influence of halopriming and organic priming on germination and seed vigour in blackgram (VignamungoL.) seeds. Journal of pharmacognosy and phytochemistry. 6(4), 537540.

25. Woolf, D, Amonette, J. E, Street-Perrott, F. A, Lehmann, J \& Joseph S. (2010). Sustainable biochar to mitigate global climate change. Nature Communication.1(56). 
26. Yousarahafeez, Sumeraiqbal, Khajistajabeen, Sobiashahzad, Summerajahan\& Fahd rasul. (2017). Effect of biochar application on seed germination and seedling growth of Glycine max (L.) merr. Under drought stress. Pakistan Journal of Botany.7-13.

27. Zaidi, R. K., \& Pathak, N. (2014). Antifungal activity of plant extracts and Trichoderma sp. against seed fungi of Cowpea. International Journal of Botany and Research.[IJBR](Trans\&Stellar). Pages, 51-60.

28. Yue, Y, Cui, L, Lin, Q, Li, G \&Zhao, X. (2017). Efficiency of sewage sludge biochar in improving urban soil properties and promoting grass growth. Chemosphere. 173, 551.

29. Zakariasolaiman, Daniel Vaughan murphy \& Abbott, L. K. (2011). Biochar influences seed germination and early growth of seedlings. Plant and Soil.353, 273-287.

\section{APPENDIES}

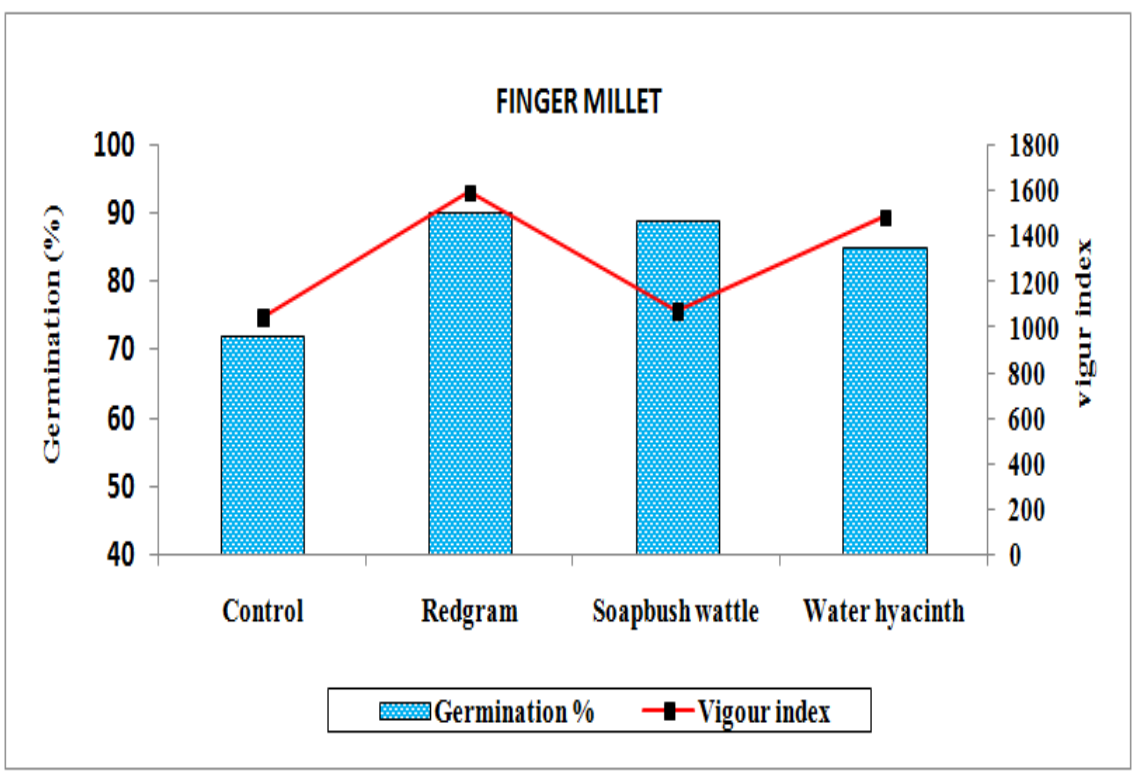

Figure 1: Evaluation of Different Biochars as Priming Agent for Seed Quality Performance

Table 1: Effect of Priming on Finger Millet Seed with Redgrambiochar as Priming Agent

\begin{tabular}{|c|c|c|c|c|c|c|}
\hline Q. P & $\begin{array}{c}\text { Speed of } \\
\text { Emergence }\end{array}$ & Germination \% & $\begin{array}{c}\text { Root } \\
\text { Length } \\
(\mathbf{c m})\end{array}$ & $\begin{array}{c}\text { Shoot } \\
\text { Length } \\
(\mathbf{c m})\end{array}$ & $\begin{array}{c}\text { Dry Matter } \\
\text { Production } \\
\text { (g/10 } \\
\text { Seedlings) }\end{array}$ & $\begin{array}{c}\text { Vigour } \\
\text { Index }\end{array}$ \\
\hline Control & 3.79 & $75(60.00)$ & 11.0 & 3.4 & 0.019 & 1075 \\
\hline BC 1\% & 4.39 & $83(65.65)$ & 12.2 & 4.0 & 0.024 & 1337 \\
\hline BC 2\% & 4.65 & $85(67.21)$ & 12.7 & 4.0 & 0.024 & 1419 \\
\hline BC 3\% & 4.81 & $88(69.73)$ & 12.1 & 4.1 & 0.026 & 1425 \\
\hline BC 4\% & 4.82 & $91(72.54)$ & 13.3 & 4.2 & 0.028 & 1591 \\
\hline BC 5\% & 4.75 & $84(66.42)$ & 12.2 & 4.1 & 0.025 & 1369 \\
\hline Mean & $\mathbf{4 . 5 3}$ & $\mathbf{8 4}(\mathbf{6 6 . 9 2})$ & $\mathbf{1 2 . 2 4}$ & $\mathbf{3 . 9 7}$ & $\mathbf{0 . 0 2 4}$ & $\mathbf{1 3 6 9}$ \\
\hline SEd & $\mathbf{0 . 1 4}$ & $\mathbf{2 . 6}$ & $\mathbf{0 . 6 0}$ & $\mathbf{0 . 1 6}$ & $\mathbf{0 . 0 0 2}$ & $\mathbf{7 4 . 5}$ \\
\hline $\begin{array}{c}\text { CD } \\
\text { (P=0.05) }\end{array}$ & $\mathbf{0 . 3 1}$ & $\mathbf{5 . 1}$ & $\mathbf{1 . 3 1}$ & $\mathbf{0 . 3 6}$ & $\mathbf{0 . 0 0 4}$ & $\mathbf{1 6 2 . 3}$ \\
\hline
\end{tabular}

*Q. P- Quality Parameters, Conc.- Concentration, BC- Biochar

(Figures in parentheses indicates arcsine values) 
Table 2: Effect of Priming on Finger Millet Seed with Soapbush Wattle Biochar as Priming Agent

\begin{tabular}{|c|c|c|c|c|c|c|}
\hline $\begin{array}{c}\text { Q. P } \\
\text { Conc. }\end{array}$ & $\begin{array}{c}\text { Speed of } \\
\text { Emergence }\end{array}$ & $\begin{array}{c}\text { Germination } \\
\text { \% }\end{array}$ & $\begin{array}{c}\text { Root } \\
\text { Length } \\
(\mathbf{c m})\end{array}$ & $\begin{array}{c}\text { Shoot } \\
\text { Length } \\
(\mathbf{c m})\end{array}$ & $\begin{array}{c}\text { Dry Matter } \\
\text { Production } \\
\text { (g/10 } \\
\text { Seedlings) }\end{array}$ & $\begin{array}{c}\text { Vigour } \\
\text { Index }\end{array}$ \\
\hline Control & 4.30 & $75(60.00)$ & 11.0 & 3.4 & 0.020 & 1074 \\
\hline BC 1\% & 5.09 & $89(70.63)$ & 13.5 & 4.2 & 0.025 & 1582 \\
\hline BC 2\% & 4.85 & $87(68.87)$ & 12.9 & 4.2 & 0.023 & 1483 \\
\hline BC 3\% & 4.85 & $83(65.65)$ & 12.3 & 4.0 & 0.021 & 1347 \\
\hline BC 4\% & 4.99 & $81(64.16)$ & 12.3 & 4.2 & 0.025 & 1341 \\
\hline BC 5\% & 4.85 & $80(64.23)$ & 12.3 & 4.1 & 0.021 & 1310 \\
\hline Mean & $\mathbf{4 . 8 2}$ & $\mathbf{8 2}(\mathbf{6 5 . 5 3})$ & $\mathbf{1 2 . 3 7}$ & $\mathbf{4 . 0 2}$ & $\mathbf{0 . 0 2 2}$ & $\mathbf{1 3 5 6}$ \\
\hline SEd & $\mathbf{0 . 2 2}$ & $\mathbf{2 . 6}$ & $\mathbf{0 . 4 2}$ & $\mathbf{0 . 1 6}$ & $\mathbf{0 . 0 0 1}$ & $\mathbf{6 8 . 9}$ \\
\hline $\begin{array}{c}\text { CD } \\
\text { (P=0.05) }\end{array}$ & $\mathbf{0 . 4 8}$ & $\mathbf{5 . 8}$ & $\mathbf{0 . 9 1}$ & $\mathbf{0 . 3 5}$ & $\mathbf{0 . 0 0 2}$ & $\mathbf{1 5 0 . 2}$ \\
\hline
\end{tabular}

*Q. P- Quality Parameters, Conc.- Concentration, BC- Biochar

(Figures in parentheses indicates arcsine values)

Table 3: Effect of Priming on Finger Millet Seed with Water Hyacinth Biochar as Priming Agent

\begin{tabular}{|c|c|c|c|c|c|c|}
\hline $\begin{array}{c}\text { Q.P } \\
\text { Conc. }\end{array}$ & $\begin{array}{c}\text { Speed of } \\
\text { Emergence }\end{array}$ & $\begin{array}{c}\text { Germination } \\
\mathbf{\%}\end{array}$ & $\begin{array}{c}\text { Root } \\
\text { Length } \\
(\mathbf{c m})\end{array}$ & $\begin{array}{c}\text { Shoot } \\
\text { Length } \\
(\mathbf{c m})\end{array}$ & $\begin{array}{c}\text { Dry Matter } \\
\text { Production } \\
(\mathbf{g} / \mathbf{1 0} \\
\text { Seedlings })\end{array}$ & $\begin{array}{c}\text { Vigour } \\
\text { Index }\end{array}$ \\
\hline Control & 5.24 & $75(60.00)$ & 10.6 & 3.4 & 0.019 & 1050 \\
\hline BC 1\% & 5.81 & $81(64.16)$ & 12.5 & 3.8 & 0.021 & 1326 \\
\hline BC 2\% & 5.39 & $83(65.65)$ & 12.1 & 3.9 & 0.025 & 1325 \\
\hline BC 3\% & 5.47 & $84(66.42)$ & 12.2 & 4.0 & 0.023 & 1354 \\
\hline BC 4\% & 5.92 & $85(67.21)$ & 13.0 & 4.3 & 0.022 & 1483 \\
\hline BC 5\% & 5.84 & $77(61.34)$ & 12.9 & 4.0 & 0.024 & 1305 \\
\hline Mean & $\mathbf{5 . 6 1}$ & $\mathbf{8 0}(\mathbf{6 4 . 2 3})$ & $\mathbf{1 2 . 2 0}$ & $\mathbf{3 . 8 9}$ & $\mathbf{0 . 0 2 2}$ & $\mathbf{1 3 0 4}$ \\
\hline SEd & $\mathbf{0 . 1 7}$ & $\mathbf{1 . 9}$ & $\mathbf{0 . 6 0}$ & $\mathbf{0 . 1 6}$ & $\mathbf{0 . 0 0 1}$ & $\mathbf{4 7 . 6}$ \\
\hline $\begin{array}{c}\text { CD } \\
\text { (P=0.05) }\end{array}$ & $\mathbf{0 . 3 7}$ & $\mathbf{4 . 2}$ & $\mathbf{1 . 3 1}$ & $\mathbf{0 . 3 6}$ & $\mathbf{0 . 0 0 3}$ & $\mathbf{1 0 3 . 9}$ \\
\hline
\end{tabular}

*Q. P- Quality Parameters, Conc.- Concentration, BC- Biochar

(Figures in parentheses indicates arcsine values) 